\title{
Information Systems Outsourcing Reasons in the Largest Spanish
} Firms.

Authors: Gonzalez, Reyes; ;asco, Jose and Llopis, Juan. University of Alicante. Facultad de Ciencias Económicas y Empresariales. Departamento de Organización de Empresas. Carretera San Vicente-Alicante. C.P. 03080. Alicante. SPAIN.

\begin{abstract}
The aim of this paper is to explore the reasons that lead to Information Systems outsourcing in the largest Spanish firms. Our paper takes as its starting point previous literature on Information Systems and tries to analyse if those reasons are related to the outsourcing level as well as to the different characteristics of the firm and its Information Systems department. With this aim, a survey was made among Information Systems managers in those firms. The results show that outsourcing gives the firms the possibility of enhancing their Information Systems services and departments.
\end{abstract}

\footnotetext{
* Corresponding Author: University of Alicante. Facultad de Ciencias Económicas y Empresariales. Departamento de Organización de Empresas. Carretera San VicenteAlicante. C.P. 03080. Alicante. SPAIN. Phone and Fax: 34-96-5903606. e-mail: mr.gonzalez@ua.es
} 


\section{Information Systems Outsourcing Reasons in the Largest Spanish}

\section{Firms.}

\section{Introduction}

The traditional concept of firm, in which the different value chain activities are carried out internally, is being replaced by the idea of a network organisation or even a virtual organisation, in which fewer and fewer operations are performed within the firm (Burn \& Ash, 2000:15; Georgantzas, 2001:171-2; Tetteh \& Burn, 2001:171-2). Only those functions which generate added value and represent the firm's competitive advantage must be performed internally; the rest of functions are outsourced (Ching, Holsapple \& Whiston, 1996:179). Some of the activities in which firms most often opt for outsourcing at present are those related to information management; as a matter of fact, outsourcing is one of the information services that has developed the most in recent years (Baldwing, Irani \& Love, 2001:16; Bryce \& Useem, 1998:635; Caldwell, 1996:51; Heeks, Krishna, Nicholson \& Sahay, 2001:54; Kern, Willcocks \& Van Heck, 2002:47; Lacity \& Willcocks, 1998:363; Marchand \& Jacobsen, 2001: 315; McLellan, Marcolin \& Beamish, 1995:300; Palvia, 1995:265; Shepherd, 1999:64; Udo, 2000:422; Willcocks, Lacity \& Kern, 1999:285).

Information Systems (IS) Outsourcing means that the physical and/or human resources related to an organisation's Information Technologies (IT) are going to be provided and/or managed by an external specialised supplier. The situation can be temporary or indefinite and can affect the client firm's whole IS, or only a part of it. This type of services became popular in the 1990's, after the spread of the success achieved by Eastman Kodak with the outsourcing of its IS (Loh \& Venkatraman, 1992). Although the IS industry had not previously used the term outsourcing explicitly, such services date back to the early years of introduction of this technology into the business world (Cheon, Grover \& Teng, 1995:210; Earl, 1996:26; Nam, Rajagopalan, Rao \& Chaudhury, 1996:36) under the format of facilities management and shared time services.

Where does the success of IS outsourcing lie? What advantages does this way of managing IS have? The Transaction Costs Theory serves as a basis for the analysis of decisions related to IS outsourcing, which is why various authors have applied it to this 
end (Ang \& Straub, 1998; Aubert, Rivard \& Patry, 1996; Buck-Lew, 1992; Cheon, Grover \& Teng, 1995; Jurison, 1995; Lacity \& Willcocks, 1995; Nam et al. 1996). That theory, originally developed by Williamson (1975), explains the reasons due to which firms produce certain goods or services internally or acquire them outside the firm through a transaction in the market, considering whether transaction costs (of negotiating and establishing relationships with external providers) exceed or not production and coordination costs using the firm's own staff.

This paper has as its aim to explore the reasons that lead to the IS outsourcing decision in the context of the largest Spanish firms. Our work's starting point is the previous literature on outsourcing fundaments or reasons, but it differs from that literature in the fact that, apart from analysing those reasons, we try to see if they are related to the outsourcing level and the different characteristics of the firm (like its size or its sector) and its IS department. We also try to find different types of firms, classified according to the reasons that led them to outsourcing. In order to reach that objective, we will first proceed to list the reasons mentioned in the existing literature on this matter after which the methodology, results and conclusions of the empirical work will be presented.

\section{The Reasons Behind IS Outsourcing Decisions}

\section{TABLE 1}

Multiple studies have analysed the reasons that most often lead to IS outsourcing. Table 1 provides a summary of the main works in this field. We can see in the table that economic considerations are important in the firm's decision to resort to outsourcing; by drastically reducing IS department size, we can transform fixed costs into variable ones and, if the contract has been properly managed, into foreseeable costs (Alner, 2001:35). The client knows what it will cost him to receive those services (Gupta \& Gupta, 1992:45) and, in some cases, he may pass cost excess on to the vendor. On the other hand, the client firm and the providing firm can take advantage of the economies of scale and scope obtained by the latter (Grover, Cheon \& Teng, 1994:37) (Jurison, 1995:239). It is easier and faster for the providing firm to achieve a return on equipment-related fixed costs, as this firm delivers services to many clients, thus achieving economies of scale. The firm also obtains economies of scope (Hayes, Hunton 
\& Reck, 2000:110) because it performs a wide variety of tasks related to IT. Another economic reason is the possible cash injection (Alner, 2001:36; Jurison, 1995:239; Smith, Mitra \& Narasimhan, 1998:65) obtained by the client when he transfers certain IS assets to the service supplier.

However, there are not only economic reasons behind outsourcing. We can detect a whole group of strategic or business factors that drive firms to IS outsourcing. Somehow, market forces are forcing firms to outsource anything that is not their core business (Gupta \& Gupta, 1992:46), and outsourcing makes it easier for firms to focus on their basic competencies (Grover, Cheon \& Teng, 1996:93; Hayes, Hunton \& Reck, 2000:110; Lacity, Hirschheim \& Willcocks, 1994:10; Smith, Mitra \& Narasimhan, 1998:64). In this way, outsourcing liberates line executives, who do not have to coordinate themselves with a large IS department, and the organisation is simplified too. Because the most monotonous, routine activities have been outsourced, computer experts can concentrate on IS key activities (Grover, Cheon \& Teng, 1994:37; Gupta \& Gupta, 1992:46).

On the other hand, we find advantages related to IS staff. For instance, outsourcing facilitates access to specialised IT management, as the supplying firm finds itself in a more advantageous position to select, train and manage technology staff. In this way, the client has access to the knowledge of high-level specialists who do not have to belong to his own staff (Alner, 2001:36). Outsourcing can additionally permit a better exploitation of the time and wit of the computer experts hired by the firm. These experts are often too highly qualified to perform routine tasks, which means that they find advantages in the outsourcing of non-critical -but daily and time-consuming- tasks that allows them to concentrate on more specialised work. As is stated by Slaughter \& Ang (1996:47), IS work is characterised by the deterioration of knowledge and the shortage of specific knowledge, and retaining the workforce with the required skill can be prohibitively expensive for a firm. With outsourcing, this problem is going to be assumed by the vendor.

Outsourcing also brings client firms advantages related to technology (Jurison, 1995:239; Lacity, Hirschheim \& Willcoks, 1994:9). The client can have access to leading-edge 
technology, without having to assume the risk of obsolescence (Clark, Zmud \& McCray, 1995:229; Grover, Cheon \& Teng, 1996:93). On the other hand, the providing firm does not have to assume a great risk either, as that risk is distributed among its wide range of clients.

Finally, we could mention other factors related to business policy which derive, amongst other things, from the possibility of repeating the success achieved by other firms that have outsourced (Smith, Mitra \& Narasimhan, 1998:64), eliminating a function that becomes problematic or complicated for the top management (Lacity, Willcocks \& Feeny, 1996:13; McFarlan \& Nolan, 1995:13), or from the intention of IS managers themselves to cause a good impression by subjecting their function to outsourcing, through which they appear as businessmen committed to corporate goals -not only as technocrats- who are willing to outsource for the good of the firm (Lacity, Hirschheim \& Willcoks, 1994:17).

Apart from all these reasons that lead to outsourcing, a whole series of risks exist that are associated with this option, e.g. the potential security problems related to the service, the unclear balance between costs and benefits, the possible IS staff opposition, the excessive dependence on the supplier, the inability to adapt to new technologies, the irreversibility of the decision once it has been made, the hidden costs generated by the contract, or the loss of basic knowledge in the client organisation (Akomode, Lees \& Ingens, 1998; Barthélemy, 2001; Dué, 1992:79-80; Earl, 1996:26-32; Fried, 1995:160-164; King \& Malhotra, 2000; Lacity \& Hirschheim, 1993b; Martinsons, 1993; Meyer, 1994:24; Palvia, 1995:269-270; Shepherd, 1999:65; Willcocks, Fitzgerald and Lacity, 1996:51, Willcocks, Lacity and Kern, 1999; Willcocks, Lacity and Fiztgerald, 1995). These risks will be greater if the client firm opts for total outsourcing, which is why a more intelligent alternative would be to resort to selective outsourcing (Judenberg, 1994:34; Jurison, 1995:239; Lacity, Willcocks \& Feeny, 1995:89; Lacity, Willcocks \& Feeny, 1996; Willcocks \& Choi, 1995:77; Willcocks, Fitzgerald \& Feeny, 1995:65). 


\section{Research Methodology}

The reason why we decided that our target population for our outsourcing study should be formed by the largest Spanish firms is similar to that provided by Fink \& Shoeib (2003: 305) in the research they carried out in Australia: since no previous data on IS outsourcing in Spain were available, we could not establish population characteristics for our study. Instead, we decided to do a survey on large Spanish organisations, assuming that they would have large IT installations and, therefore, would have greater knowledge and experience with IT outsourcing. In order to determine our target population, we have used the directory Las 5.000 mayores empresas (The 5,000 largest firms) of Actualidad Económica magazine, which has been collated with other databases largely used in business studies like Duns and Bradstreet. 50.000 Principales Empresas Españolas (the 50,000 main Spanish firms). Among the 5,000 firms with the highest turnover, we tried to find in the list of the first database mentioned above which ones had the same telephone numbers and addresses, as this was a symptom revealing that both the IS manager and the structure itself could coincide. Once that information was known to us, we decided to send the questionnaire only to the firm which, having the same telephone number and address as others, had the highest sales.

In this way, we eliminated 584 firms, after which our final database consisted of 4,416 firms, to which was sent a questionnaire along with a stamped addressed envelope for the questionnaire to be returned. We found the handicap that field studies based on surveys on IS outsourcing do not proliferate, case studies being more common (Aubert, Rivard \& Patry; 1996; Baldwing, Irani \& Love, 2001; Huber, 1993; Kern \& Willcocks, 2000; Kern \& Willcocks, 2002; Lacity \& Hirschheim, 1993a; 1993b; Lacity \& Willcocks, 1997; Lacity, Willcocks \& Feeny, 1996; Loebbecke \& Jelassi, 1999; McLellan, Marcolin \& Beamish, 1995; Palvia, 1995; Willcocks \& Choi, 1995; Willcocks, Fitzgerald \& Lacity, 1996; Willcocks, Lacity \& Kern, 1999). However, on the basis of literature on this matter (Arnett \& Jones , 1994; Clark, Zmud \& McCray, 1995; Collins \& Millen, 1995; Corbett, 1994; Grover, Cheon \& Teng, 1994) we prepared a questionnaire draft, which was later subjected to a pilot test and a pre-test. 5 out of the 19 questions of the final questionnaire were used in this study, as this paper is part of a larger empirical study 
which deals with a wide range of aspects related to IS outsourcing. The questionnaire's addressee was the IS manager of the firms included in the final database. A new inconvenience arose here, because unlike what happens in other countries, no lists about these managers are available in Spain, which means that the addressee's identity was unknown.

The information obtained in the questionnaire was later elaborated using the statistical program SPSS for Windows and treated with univariant and multivariant statistical methods. Table 2 shows the study specifications.

TABLE 2

\section{Results}

We now present the results of the empirical work; firstly, we show some general features of the firms, such as their outsourcing level or the size and characteristics of their IS department. These data are necessary to be able to check, in the following subsection, what the reasons are to outsource, and whether these reasons are influenced by the above-mentioned features. We will finally provide a typology of firms, according to which reasons are most important for outsourcing.

\subsection{General characteristics of the firms}

Table 3 shows the outsourcing levels of the target firms and some of their general features. We check that IS outsourcing is a widespread phenomenon, since only $14.3 \%$ of the interviewed firms have not outsourced any IS services. The outsourcing level variable will help us to determine if the firms' higher or lower outsourcing level conditions the reasons these firms have to outsource their IS services. Thanks to the way in which this variable was designed, a fair distribution of firms with outsourcing levels above and below average is possible.

The size of a firm can be measured by the number of employees and its sales. Table 3 shows that the interviewed firms are very large with respect to these two variables, since the lowest percentages are found in the smallest firms (only $6.2 \%$ of them have between 0 and 50 workers and $10.1 \%$ turn over up to 5 billion pesetas, ca. 30 million $€$.). Most of the interviewed firms belong to the Industrial sector (58.8\%) followed by the Service sector in which one third of the firms are included. We have detected that $8.1 \%$ 
of the answers came from firms belonging to the Financial Institutions and Insurance sector.

Despite the size of the firms, IS departments do not have a large staff. As is shown in Table 3, most firms have between 1 and 10 employees, and only very few have IS departments with more than 100 employees. The budget firms allocate to IS with respect to the firm's total budget is equally quite low. It can also be seen in the same table that most firms dedicate between 0 and $4 \%$ of their budgets to IS, and only very few dedicate more than to $11 \%$ to this department, the maximum budget percentage allocated to IS being $30 \%$ (we must point out that the percentage of the budget dedicated to IS was the question in the study which had the least answers, which means that questions referring to this aspect must be treated with caution). In short, both the IS department staff and the percentage of the budget allocated to this function prove that, regardless of firm size, only few human or financial resources are assigned to these departments.

\section{TABLE 3}

\subsection{Outsourcing reasons}

Table 4 shows the reasons leading to the outsourcing of IS services. We must say that, in the corresponding question and following the pattern of previous studies (Collins \& Millen, 1995:8), the interviewees were asked to identify the three reasons they considered to be the most important ones. Therefore, the resulting variables are dichotomical, with a 0 value if they have not mentioned a certain reason and a 1 value if they have; the $\mathrm{N}$ in the table indicates the number of times interviewees have placed one particular reason among the three most important ones.

\section{TABLE 4}

We can see that the most important reasons are, in order of priority, the possibility that outsourcing offers to focus on IS strategic matters, the potentially increased IS department flexibility, and the chance to improve quality and to get rid of monotonous, problematic tasks that are precisely the ones firms try to outsource. The reasons based on staff or technology cost savings do not appear among the ones most often mentioned by interviewees (they are ranked $5^{\text {th }}$ and $7^{\text {th }}$ ). Having access to new technologies does 
not appear either as one of the most relevant reasons, as it is ranked $6^{\text {th }}$. In short, we can say that, in general, reasons for IS outsourcing spin around the improvement of the IS department and of the services it supplies, reasons related to costs or the correction of technological deficiencies being less important.

Next, we are going to relate outsourcing reasons to other features of the firms such as outsourcing level and the size and characteristics of its IS department with the aim of determining whether or not those reasons depend on the firm's profile ${ }^{1}$.

In first place, firms with the highest outsourcing level are the ones which choose outsourcing mostly to reduce staff costs and to make easier access to new technologies; however, this does not mean that they want to find alternatives to in-house IS, as these are the firms that least mention this reason.

On the other hand, firms with the lowest number of workers are the ones that most often claim outsourcing can be a way to have access to new technologies and those that least resort to outsourcing to be able to focus on strategic aspects of the corresponding department.

Regarding the possible relationships between the reasons to outsource mentioned by the different firms, depending on their sales level, the following ones have been detected:

- Firms with the lowest sales are the ones that most often seek outsourcing as a way to save on technology.

- These firms are also the ones that most often view outsourcing as a way to facilitate access to new technologies.

- Besides, these firms see in outsourcing a possibility to improve IS service quality.

- On the contrary, firms with a higher sales level are the ones that most often resort to outsourcing to be able to focus on the most strategic IS problems, while firms with less sales level are the ones that least mention this reason.

It can be deduced that smaller firms in terms of sales and number of workers seek outsourcing basically as a way to gain access to new technologies, not with the aim of focusing on strategic aspects, unlike what happens in larger firms.

${ }^{1}$ Contingency tables and the chi-square test were applied to determine the rest of the results in the subheading 4.2. Readers could apply for further details to the corresponding author. 
We can also find important dependence relationships between outsourcing reasons and the sector the firm belongs to. On the one hand, insurance and financial institutions are the ones that have least resorted to outsourcing in order to have access to new technologies. We assume they have such sophisticated IS departments that the acquisition of leading-edge technology must be controlled internally, without relying on external suppliers. However, service firms are the ones that resort the most to outsourcing for this reason. On the other hand, financial and insurance institutions have not resorted to outsourcing in order to improve IS service quality either, a strategy that is more commonly adopted by industrial firms though.

We can also see that the size of the IS department staff is somehow related to the most often mentioned outsourcing reasons. Thus, firms with fewer staff in their IS departments are the ones that most often resort to outsourcing in order to save costs on technology, to facilitate access to new technologies and to improve the quality of the service supplied (in short, to correct deficiencies), these being reasons that were less often mentioned by firms with more staff. The latter resort more to outsourcing with the aim of focusing on IS strategic issues.

\subsection{Cluster analysis of outsourcing reasons}

Our next task was going to consist in carrying out a cluster analysis based on the variables that define outsourcing reasons ${ }^{2}$. The objective of this analysis is to group firms according to the different reasons that made them resort to outsourcing. This type of analysis is usually performed on the basis of the factor scores of each case with respect to the factors formed in a principal components factor analysis. However, it is not convenient to do a factor analysis in this case, which is why we must work with the question's original references that have to do with outsourcing reasons. We excluded the joining the fashion variable, because, due to the fact that many scores equal zero, the results become distorted (it must be remembered that we are working with dichotomical variables of value 0 , if a specific reason does not score, and value 1 , if that reason scores).

\footnotetext{
${ }^{2}$ Readers could apply for further details about the cluster analysis to the corresponding author.
} 
Once the variables that are going to intervene in the cluster analysis have been chosen, we first carry out a hierarchical conglomerate analysis (in this case, using the InterGroup Link Method -the most suitable method for ordinal or dichotomical variables), with which we want to identify the ideal number of clusters or groups. Later, after deciding the number of groups, a non-hierarchical method is used to form these groups, and results are validated with the ANOVA analysis or the corresponding non-parametric test (the Kruskall-Wallis test).

In this sense, with the aim of selecting the groups in the hierarchical method, we pay attention to the dendrogram and the agglomeration coefficient. In our study, the number of cases is so high (357 observations) that the dendrogram (a graph that represents the way in which the different groups have been formed, that is to say, it shows how similar or different observations are to one another) becomes nearly impossible to interpret. For this reason, we will have to take the agglomeration coefficient as the basis for the determination of the number of groups.

The analysis of agglomeration coefficients reveals that the most suitable number of clusters is three, as working with three groups makes it possible to see the greatest differences in coefficient percent changes. Taking this into account, we again selected variables related to outsourcing reasons and carried out a non-hierarchical conglomerate analysis (the k-means method), validating the result with an ANOVA analysis and checking that this analysis is appropriate, because all the variables included in it are relevant.

The three resulting groups are formed by 125 cases in the first one, 116 in the second, and 65 cases in the last group. Therefore, out of 357 interviewed firms, there are 51 firms we have not been able to classify in any of the clusters. These 51 firms are the ones which have outsourced no IS activities (see Table 3) and thus have not answered the questions about outsourcing reasons. Then we must proceed to interpret the three groups that have been created and identify, in turn, the differences existing between them.

The first cluster (with 125 firms) is made up of firms which assign more importance to the following outsourcing reasons: increasing IS department flexibility, having an easier 
access to new technologies and being able to focus on the most strategic IS matters. The same firms give lower scores to the following outsourcing reasons: saving technology costs and saving staff costs. Therefore, this group is formed by firms which resort to outsourcing mainly to improve their IS, without worrying so much about the costs this generates.

The second cluster is made up of 116 firms, which value, above all, staff cost saving as the main outsourcing reason. However, these are the firms that give the lowest scores to other reasons such as the possibility of getting rid of monotonous, problematic tasks, the improvement of IS service quality and providing alternatives to in-house IS. Therefore, this group includes firms seeking staff cost saving without worrying about improving IS. The third cluster is formed by 65 firms which give the highest scores to the following outsourcing reasons: saving technology costs, getting rid of IS monotonous, problematic tasks, improving service quality, and providing alternatives to internal IS. These firms are the ones which give the lowest scores to other reasons such as: increasing IS department flexibility, facilitating access to new technologies, and focusing on IS strategic problems. In short, this group is made up of firms which basically justify outsourcing as a way to save on technology but also as a way to improve IS; however, they do not see in outsourcing the possibility of focusing on the strategic problems of this service.

The first cluster is the most numerous one with 125 firms, which confirms the significant improvement outsourcing can bring to firms' IS. Nevertheless, we must also bear in mind that a considerable number of firms (116) are located in the second cluster, which also reminds us that many firms do not seek outsourcing in order to improve their service, but mainly to save staff costs.

After describing these characteristics, it would be interesting to check if each group can be identified with a specific type of firm, based on their outsourcing level, their size, their activity sector, as well as other characteristics that are typical of an IS department like its staff or its budget. However, the statistical analysis shows the absence of dependence relationships; in other words, there is no direct correspondence between each cluster and a specific firm size, a sector or a type of IS department. 


\section{Summary and Conclusions}

The most important reasons why large Spanish firms outsource their IS activities are, in order of priority, the possibility outsourcing gives to focus on IS strategic matters, the possible increase in IS department flexibility, and the chance to get rid of routine, problematic tasks, the ones firms are trying to outsource. In general, the reasons to outsource IS focus on the improvement of the IS department and the services it supplies, reasons related to costs and correction of technological deficiencies being less important.

The reasons to outsource IS are mainly influenced by the size of the firm and the sector it belongs to, the outsourcing level and the size of the staff dedicated to IS being very relevant too. We conclude that smaller firms in terms of turnover and number of staff basically resort to outsourcing in order to gain access to new technologies and not to focus on strategic aspects, unlike what happens in larger firms. On the other hand, insurance and financial institutions are the ones which least resort to outsourcing to make easier access to new technologies and to improve IS quality. We suppose that they have IS departments that can control by themselves the acquisition of leading-edge technology, without having to rely on external suppliers. However, industrial firms are the ones that resort the most to outsourcing in order to improve quality, while service firms seek access to new technologies, which reveals possible shortages in the field of IT in these sectors.

Then, we set ourselves the task of carrying out a cluster analysis based on the variables that define the reasons for the success of outsourcing. The objective of this analysis is to group firms according to the different reasons that led them to outsourcing. The first group is formed by firms that resort to outsourcing mainly to improve their IS, without paying so much attention to the costs this generates. The second cluster is made up of firms seeking staff cost saving without worrying about IS improvement. The third cluster includes firms which justify outsourcing as a way to save on technology, but also to improve IS; however, they do not see in outsourcing an opportunity to focus on the strategic problems of this service. The first cluster is the most numerous one with 125 firms, which proves the significant improvement outsourcing can bring to firms' IS. 
Nevertheless, we must also bear in mind that a considerable number of firms (116) are located in the second cluster, which also reminds us that many firms do not seek outsourcing in order to improve their service, but mainly to save staff costs. There is no direct correspondence between each cluster and a specific firm size, sector or type of IS department, which has prevented us from confirming or denying the associations mentioned in the previous paragraph.

Regarding the limitations of our study, we can first refer to those derived from the use of the questionnaire as the essential method to obtain results. Even though there is the advantage of being able to address a large population, there are also important disadvantages: the qualitative information collected in a personal interview or through direct observation is richer. In surveys, interviewees may have answered what is politically correct, not what is real.

Other limitations can result from the design of the questionnaire, in which we gave up the wealth of the information obtained (and even the potential application of statistical methods better than the ones we used) and looked for simple answers, trying to maximise the number of surveys answered. This is why the question about outsourcing reasons gives rise to dichotomical variables, which limits us quite a lot in terms of performing certain statistical analyses (for instance, factor analysis).

Some of these limitations could be overcome in future by carrying out a Delphi analysis in which we would ask the IS managers who have showed interest in our study for their collaboration.

\section{References}

Akomode, O.J.; Lees, B. \& Ingens, Ch. (1998). Constructing Customised Models and Providing Information to Support IS Outsourcing Decisions. Logistics Information Management, 11 (2), 114-127.

Alner, M. (2001). The Effects of Outsourcing on Information Security. Information Systems Security, 10 (2), 35-43.

Ang, S. \& Straub, D. (1998). Production and Transaction Economies and IS Outsourcing: A Study of the U.S. Bank Industry. MIS Quarterly, 22 (4), 535-552. 
Arnett, K.P. \& Jones, M.C. (1994). Firms that Choose Outsourcing: A Profile. Information and Management, 26 (4), 179-188.

Aubert, B.A.; Rivard, S. \& Patry, M.A. (1996). Transaction Cost Approach to Outsourcing Behavior: Some Empirical Evidence. Information and Management, 30 (2), 51-64.

Baldwing, LP; Irani, Z. \& Love, P. (2001). Outsourcing Information Systems: Drawing Lessons from a Banking Case Study. European Journal of Information Systems, 10 (1), 1524.

Barthélemy, J. (2001). The Hidden Cost of IT Outsourcing. MIT Sloan Management Review, 42 (3), 60-69.

Bryce, D.J. \& Useem, M. (1998). The Impact of Corporate Outsourcing on Company Value. European Management Journal, 16 (6), 635-643.

Buck-Lew, M. (1992). To Outsource or Not? International Journal of Information Management, 12, 3-20.

Burn, J.M. \& Ash, C. (2000). Knowledge Management Strategies for Virtual Organizations. Information Resources Management Journal, 13 (1), 15-23.

Caldwell, B. (1996). The New Outsourcing Partnership. Information Week, (585), 50-64.

Cheon, M.; Grover, V. \& Teng, J. (1995). Theoretical Perspectives on the Outsourcing of Information Systems. Journal of Information Technology, 10 (4), 209-219.

Ching, Ch., Holsapple, C.W. \& Whinston, A.B. (1996). Toward IT Support for Coordination in Network Organizations. Information and Management, 30 (4), 179-199.

Clark, T.D.; Zmud, R.W. \& McCray, G.E. (1995). The Outsourcing of Information Services: Transforming the Nature of Business in the Information Industry. Journal of Information Technology, 10 (4), 221-237.

Collins, J.S. \& Millen, R.A. (1995). Information Systems Outsourcing by Large American Industrial Firms: Choices and Impacts. Information Resources Management Journal, 8 (1), $5-13$.

Corbett, M.F. (1994). Outsourcing and the New IT Executive. A Trends Report. Information Systems Management, 11 (4), 19-22.

Dué, R.T. (1992). The Real Cost of Outsourcing. Information Systems Management, 9 (1), 78-81. 
Earl, M.J. (1996). The Risk of Outsourcing IT. Sloan Management Review, 37 (3), 26-32.

Fink, D. \& Shoeib, A. (2003). Action: the most critical phase in outsourcing information technology. Logistics Information Management, 16(5), 302-311.

Fried, L. (1995). Managing Information Technology in Turbulent Times. New York: Wiley.

Georgantzas, N.C. (2001). Virtual enterprise networks: the fifth element of corporate governance. Human System Management, 20 (3), 171-188.

Grover, V.; Cheon, M.J. \& Teng, T.C. (1994). A Descriptive Study on the Outsourcing of Information Systems Functions. Information and Management, 27 (1), 33-44.

Grover, V.; Cheon, M.J. \& Teng, T.C. (1996). The Effect of Service Quality and Partnership on the Outsourcing of Information Systems Functions. Journal of Management Information Systems, 12 (4), 89-116.

Gupta, G. \& Gupta, H. (1992). Outsourcing the IS function. Is it necessary for your organization? Information Systems Management, 9 (3), 44-50.

Hayes, D.C. ; Hunton, J.E. \& Reck, J.J. (2000). Information Systems Outsourcing Announcements: Investigating the Impact on the Market Value of Contract-Granting Firms. Journal of Information Systems, 14 (2), 109-125.

Heeks, R.; Krishna, S. ; Nicholson, B. \& Sahay, S. (2001). Synching or Sinking: Global Software Outsourcing Relationships. IEEE Software, 18 (2), 54-60.

Huber, R.L. (1993). How Continental Bank Outsourced its «Crown Jewels». Harvard Business Review, January-February, 121-129.

Judenberg, J. (1994). Applications Maintenance Outsourcing. An Alternative to Total Outsourcing. Information Systems Management, 11 (4), 34-38.

Jurison, J. (1995). The Role of Risk and Return in Information Technology Outsourcing Decisions. Journal of Information Technology, 10 (4), 239-247.

Kern, T. \& Willcocks, L. (2000). Exploring Information Technology Outsourcing Relationship: Theory and Practice. Journal of Strategic Information Systems, 9 (4), 321350.

Kern, T. \& Willcocks, L. (2002). Exploring Relationships in Information Technology Outsourcing: the Interaction Approach. European Journal of Information Systems, 11 (1), 3-19. 
Kern, T.; Willcocks, L.P. \& Van Heck., E. (2002). The Winner's Curse in IT Outsourcing: Strategies for Avoiding Relational Trauma. California Management Review, 44 (2), 4769.

King, W.R. \& Malhotra, Y. (2000). Developing a Framework for Analyzing IS Outsourcing. Information and Management, 37 (6), 323-334.

Lacity, M. \& Hirschheim, R. (1993a). Implementing Information Systems Outsourcing: Key Issues and Experiences of an Early Adopter. Journal of General Management, 19 (1), 1731.

Lacity, M. \& Hirschheim, R. (1993b). The Information Systems Outsourcing Bandwagon. Sloan Management Review, 35 (1), 73-86.

Lacity, M.; Hirschheim, R. \& Willcocks, L. (1994). Realizing Outsourcing Expectations. Incredible Expectations, Credible Outcomes. Information Systems Management, 11 (4), 718.

Lacity, M. \& Willcocks, L. (1995). Interpreting Information Technology Sourcing Decisions from a Transaction Cost Perspective: Findings and Critique. Accounting, Management and Information Technology, 5 (3/4), 203-244.

Lacity, M. \& Willcocks, L. (1997). Information Systems Sourcing: Examining the Privatization Option in USA Public Administration. Information Systems Journal, (7), 85108.

Lacity, M. \& Willcocks, L. (1998). An Empirical Investigation of Information Technology Sourcing Practices: Lessons from Experience. MIS Quarterly, 22 (3), 363-408.

Lacity, M.; Willcocks, L. \& Feeny, D. (1995). IT Outsourcing Maximize Flexibility and Control. Harvard Business Review, May-June, 84-93.

Lacity, M.C.; Willcocks, L.P. \& Feeny, D.F. (1996). The Value of Selective Sourcing. Sloan Management Review, 137 (3), 13-25.

Loebbecke, C. \& Jelassi, T. (1999). Business Strategies and IT Outsourcing: The Case of Compunet AG. European Management Journal, 17 (6), 615-624.

Loh, L. \& Venkatraman, N. (1992). Diffusion of Information Technology Outsourcing: Influence sources and the Kodak Effect. Information Systems Research, 3 (4), 334-358. 
Marchand, N. \& Jacobsen, H-A. (2001). An Economic Model to Study Dependencies between Independent Software Vendors and Application Service Providers. Electronic Commerce Research, 1 (3), 315-334.

Martinsons, M.G. (1993). Outsourcing Information Systems: A Strategic Partnership with Risk. Long Range Planning, 26 (3), 18-25.

McFarlan, F.W. \& Nolan, R.L. (1995). How to Manage an IT Outsourcing Alliance. Sloan Management Review, 36 (2), 8-23.

McLellan, K.; Marcolin, B. \& Beamish, P. (1995). Financial and Strategic Motivations behind IS Outsourcing. Journal of Information Technology, 10 (4), 299-321.

Meyer, N.D. (1994). A Sensible Approach to Outsourcing. The Economic Fundamentals. Information Systems Management, 11 (4), 23-27.

Nam, K. ; Rajagopalan, S ; Rao, H.R. \& Chaudhury, A. (1996). A Two-Level Investigation of Information Systems Outsourcing. Communications of the ACM, 39 (7), 36-44.

Palvia, P.C. (1995). A Dialectic View of Information Systems Outsourcing: Pros and Cons. Information and Management, 29 (5), 265-275.

Shepherd, A. (1999). Outsourcing IT in a Changing World. European Management Journal, 17 (1), 64-84.

Slaughter, S. \& Ang, S. (1996). Employment Outsourcing in Information Systems. Communications of the ACM, 39 (7), 47-54.

Smith, M.A.; Mitra, S. \& Narasimhan, S. (1998). Information Systems Outsourcing: A Study of Pre-Event Firm Characteristics. Journal of Management Information Systems, $15(2), 61-93$

Tetteh, E. \& Burn, J. (2001). Global strategies for SME-business: applying the SMALL framework. Logistic Information Management, 14 (1/2), 171-180.

Udo, G.G. (2000). Using Analytic Hierarchy Process to Analyze the Information Technology Outsourcing Decision. Industrial Management and Data Systems, 100 (9), 421-429.

Willcocks, L. \& Choi, Ch.J. (1995). Co-operative Partnership and 'Total' IT Outsourcing: From Contractual Obligation to Strategic Alliance? European Management Journal, 13 (1), 76-78. 
Willcocks, L.; Fitzgerald, G. \& Feeny, D. (1995). Outsourcing IT: The Strategic Implications. Long Range Planning, 28 (5), 59-70.

Willcocks, L.; Fitzgerald, G. \& Lacity, M, (1996). To Outsource or not? Recent Research on Economics and Evaluation Practice. European Journal of Information Systems, 5, 143-160.

Willcocks, L.; Lacity, M. \& Fitzgerald, G. (1995). Information Technology Outsourcing in Europe and in the USA: Assessment Issues. International Journal of Information Management, 15 (5), 333-351.

Willcocks, L.P., Lacity, M.C. \& Kern, T. (1999). Risk Mitigation in IT Outsourcing Strategy Revisited: Longitudinal Case Research at LISA. Journal of Strategic Information Systems, 8 (3), 285-314.

Williamson, O.E. (1975). Markets and Hierarchies. Analysis and Antitrust Implications. New York: The Free Press. 
Table 1: Outsourcing reasons: a background on literature

\begin{tabular}{|c|c|}
\hline REASONS & RGUMENT \\
\hline \multicolumn{2}{|r|}{ Alner (2001:35-36) } \\
\hline Cost reduction & $\begin{array}{l}\text { Long-term outsourcing contracts convert variable costs into fixed costs, and make } \\
\text { technology spending more predictable. }\end{array}$ \\
\hline Tax advantage & $\begin{array}{l}\text { Tax advantage comes from the ability to deduct the expense of outsourcing fees from } \\
\text { current year earnings as opposed to depreciating an internal data processing department's } \\
\text { hardware assets over time. }\end{array}$ \\
\hline Yielding capital & $\begin{array}{l}\text { Outsourcing agreements can yield capital for cash strapped organizations if the outsourcer } \\
\text { purchases the client's hardware assets. }\end{array}$ \\
\hline $\begin{array}{l}\text { Cash } \\
\text { improvements }\end{array}$ & $\begin{array}{l}\text { Companies that outsource enjoy cash flow improvements resulting from the transfer of } \\
\text { software licenses and personnel to the outsourcer. }\end{array}$ \\
\hline $\begin{array}{ll}\text { Guaranteed } & \text { service } \\
\text { and } & \text { system } \\
\text { availability } & \end{array}$ & Outsourcing providers guarantee service and system availability. \\
\hline $\begin{array}{l}\text { The client can focus } \\
\text { on business planning }\end{array}$ & $\begin{array}{l}\text { In an outsourcing relationship, software and hardware upgrades become the concern of the } \\
\text { outsourcer rather than a distraction to the senior management. }\end{array}$ \\
\hline $\begin{array}{l}\text { Hiring and retaining } \\
\text { highly-trained } \\
\text { technology } \\
\text { professionals }\end{array}$ & $\begin{array}{l}\text { The core business focus of outsourcing providers is on technology, so their staff are well- } \\
\text { informed of emerging technologies and their implementation within specific industries. }\end{array}$ \\
\hline \multicolumn{2}{|r|}{ Ang \& Straub (1998:537-538) } \\
\hline $\begin{array}{l}\text { Production cost } \\
\text { economies }\end{array}$ & $\begin{array}{l}\text { A firm will choose to outsource or insource on the basis of the comparative costs of } \\
\text { internalising IS as opposed to the price it has to pay vendors for the same IS services. }\end{array}$ \\
\hline $\begin{array}{l}\text { Transaction cost } \\
\text { economies }\end{array}$ & $\begin{array}{l}\text { Transaction costs refer to the effort, time, and costs incurred in searching, creating, } \\
\text { negotiating, monitoring, and enforcing a service contract between buyers and suppliers. } \\
\text { Firms may opt for internal sourcing when they perceive transaction diseconomies to } \\
\text { override any production cost advantages in market exchanges. }\end{array}$ \\
\hline Financial slack & $\begin{array}{l}\text { If investments in IT can promote social prominence and public prestige, managers are } \\
\text { induced to invest slack resources on internalising IS services. When slacks resources are } \\
\text { low, firms can be expected to downsize internal IS services by selling off IT assets and } \\
\text { reducing IS staff expenses. }\end{array}$ \\
\hline \multicolumn{2}{|r|}{ Baldwing, Irani \& Love (2001:23) } \\
\hline $\begin{array}{l}\text { Strategic and } \\
\text { organizational }\end{array}$ & $\begin{array}{l}\text { Focusing on core business. Eliminating a troublesome IT function. Gaining access to high- } \\
\text { quality IT services and skills. Reducing a backlog of application developments. } \\
\text { Restructuring of IT, i.e. downsizing. Handling fluctuating IT demands. Exploiting new } \\
\text { technologies. Market testing. Share risk and rewards. Quick response to IT needs. } \\
\text { Accelerating reengineering benefits. }\end{array}$ \\
\hline $\begin{array}{l}\text { Policy and other } \\
\text { reasons }\end{array}$ & $\begin{array}{l}\text { Government legislation. Credibility enhancement. Solving internal conflicts. Reaction to the } \\
\text { bandwagon. }\end{array}$ \\
\hline Technical reasons & $\begin{array}{l}\text { Access to expertise/technology. Perceived poor performance of internal staff. Access to } \\
\text { better quality services. }\end{array}$ \\
\hline Economics & $\begin{array}{l}\text { Saving costs. Generating a cash flow. Converting capital assets into revenue. Control } \\
\text { accountability. Freeing resources for core activities. Controlling IT costs (cost } \\
\text { predictability). }\end{array}$ \\
\hline \multicolumn{2}{|r|}{ Clark, Zmud \& McCray, (1995:228-230) } \\
\hline $\begin{array}{l}\text { Reducing cost and/or } \\
\text { injecting cash }\end{array}$ & $\begin{array}{l}\text { There are numerous paths through which such benefits might materialize: disengaging the } \\
\text { firm from costly, outdated technological resources, transforming information services from } \\
\text { a fixed asset into a variable expense, which can be reduced or increased according to } \\
\text { business requirements, reducing staffing levels and transferring personnel to a vendor, or } \\
\text { reducing overhead expenses (administration, office space, air conditioning, and so on). }\end{array}$ \\
\hline Deve & $\begin{array}{l}\text { floading IS activities to a vendor enables a firm to focus its internal resources and } \\
\text { ergies on those IS activities which remain internal. }\end{array}$ \\
\hline
\end{tabular}

applications more

rapidly

Improving service

quality and

productivity

Gaining access to leading-edge technologies

Reducing technological risk and increasing technological flexibility
This occurs for numerous reasons. For example, the vendor may have access to more current technological environments, have better qualified or more motivated personnel, have better management systems with which to coordinate or control service provision, and simply be more committed than in-house staff to making the alliance with the costumer work well.

Developing close relationships with external vendors enables a firm not only to utilize the vendor's technologies but also to tap into the vendor's links with other technology providers and users. Also, as firms making effective use of outsourcing should have less capital tied up in ageing technologies, these firms generally have more funds available to acquire newer technologies that are needed internally.

The vendor rather than the firm must bear the risks of both technological obsolescence and variable service demand. 
Implementing changes more rapidly

Assessing current information management capabilities

Enhancing the status of the senior information services executive

Facilitating information services management tasks for the senior management

Strategic factors

Economic factors

Technological factors risk; due to the accelerated changes in the nature of the IT infrastructure, the risk of obsolescence is high.

Gupta \& Gupta (1992:45-47)

Strategic focus

Market forces

Technical considerations 
Importance of core competencies

Flexibility

Cost reduction
By transferring resources from non-value-added staff functions to value-added core competency functions.

Given the increasingly rapid pace of technological changes witnessed in recent years, many firms stand to gain a significant advantage from IS outsourcing, in the sense that outsourcing firms will not become technologically obsolete. Firms can increase their flexibility by permanently redesigning their contracts to meet their information needs.

While reducing costs might positively impact a firm's value in the short term, it is questionable whether an IS outsourcing strategy aimed solely at reducing costs will enhance or protect firm value in the long term. The reasoning behind this concern is that cutting costs may cause a firm to indiscriminately outsource IS functions, as a result of which the firm might not separate non-value-added IS functions from value-added core competency IS functions.

\section{Jurison (1995:239-240)}

Cost savings through A vendor can often achieve economies of scale that may not be achievable internally and economies of scale Cash injection

Faster applications development

Improved service and Does not argue.

quality

Access to IT

expertise and

competence

Access to new

technologies

Flexibility in

managing IT

resources

Elimination of a troublesome function

Cash infusion

that IS

are not efficient

Perception that IS

are not effective

Perception that IS

are not technically

competent

Ability to focus on more strategic issues

Financial
expectations

Business

expectations pass back some of the savings on to the client.

Does not argue.

Does not argue.

Some firms may find it difficult, time-consuming, or expensive to hire new staff, especially if a special technical expertise is needed.

Does not argue.

The objective in this case is to cope more easily with the increasing volatility in business volume and let the vendor absorb fluctuations in the IT workload.

Does not argue.

Lacity \& Hirschheim (1993a:19-21)

Industries in distress are still the best sales prospects for outsourcing vendors.

When the IS department is perceived to be inefficient, a vendor can reduce costs.

The perception is that outsourcing vendors are IS professionals, and therefore better able to effectively manage the IS function.

Outsourcing vendors are able to keep up with the technology curve; vendors can adapt quickly to machine upgrades and new software releases.

Management claims that non-strategic functions are outsourced so that they can concentrate on more strategic issues.

Lacity, Hirschheim \& Willcocks (1994:9-17)

Cost reductions, mainly because vendors enjoy economies of scale that enable them to provide IT services at a lower cost than internal departments. Improved cost control, because vendors implement cost controls that more directly tie use to cost. Restructuring IT budgets to more flexible operating budgets.

A return to core competencies, whereas more monotonous, non-strategic IS activities are outsourced. Facilitating mergers and acquisitions, as outsourcing can solve technical incompatibilities, absorb excess IT assets and the additional IT employees generated by mergers and acquisitions. Providing IT for start-up companies, as outsourcing can be a quicker and less expensive way to provide IT services, when start-up companies simply could not afford the capital investment required to create in-house IT departments.

Technical

expectations

Improving technical service because the outsourcing vendor could possess a technical expertise that internal IT departments lack. Access to technical talent, as many firms find it difficult to hire or retain staff with the desired state-of-the-art technical skills. Gaining access to new technologies, with access to the products of the vendors' large research and development departments.

Policy expectations Proving IT internal department efficiency, because an outsourcing evaluation would show the senior management that the internal IT department was cost efficient. Justifying new resources, such as machine upgrades and additional staff, showing that growth cannot be achieved more efficiently through outsourcing. To duplicate outsourcing success stories. Eliminating a troublesome function, because it is not uncommon for IT to be perceived by the senior management as a headache. Breaking the "glass ceiling": IT personnel rarely reach the upper echelons of management. Hence, IT managers may initiate outsourcing decisions with the purpose of enhancing their credibility. By showing that they are willing to outsource their kingdom for the good of the company, they show the senior management that they are business professionals committed to corporate goals, not technocrats attempting to build technology empires. 
General Managers' concern about Costs and Quality

Breakdown in IT performance

Strong supplier pressures

Simplified General

Management Agenda

Financial factors

Corporate culture

Elimination of an internal irritant

Financial motivations Cost savings (these include hardware costs, software costs, IS personnel costs and business operations costs).Efficiency improves dramatically for hardware activities, software purchasing and IS staff size. Effectiveness is reflected in terms of more appropriate and tailored software, a greater range and flexibility in IS task assignments, as well as better business operational integration and consolidation.

Strategic motivations Contrary to the conventional belief, firms that see IS as a core function that needs a tight control resort to outsourcing. Outsourcing offers an opportunity to use resources beyond those contained in the firm to increase competitive capabilities within the IS function.

\section{Slaughter \& Ang (1996:47)}

To solve issues related to the IS labour market IS work is characterized by skills deterioration and specific skill shortages. Thus, a firm's ability to find and acquire the necessary IS skills is paramount. Under these circumstances, relying on retraining a permanent workforce may have a prohibitive cost.

\section{Smith, Mitra \& Narasimhan (1998:64-65)}

Cost reduction It is commonly believed that an outside vendor can provide the same level of service at a lower cost than the internal IS department. The often cited rationale is that the vendor typically has better economies of scale, tighter control over fringe benefits, better access to lower-cost labour pools, and more focused expertise in managing IS.

Focus on core competencies Companies may outsource their IS to simplify the management agenda and focus on the firm's core business. If managers do not see a strategic role for IS, then IS outsourcing is often viewed as a means of preserving managerial effort and focusing on areas with greater strategic potential. Also, firms can outsource a significant portion of the IS infrastructure, while still retaining those aspects that are viewed as strategic.

Cash needs Companies often outsource IS to generate cash. An important part of many IS outsourcing agreements is an introductory cash payment by the vendor for the client's tangible and intangible IT assets.

IS capability factors Because of rapid technological advances, a firm's IS department may lack current technical expertise and equipment. Internal policies, dissatisfaction with the IS department, lack of trust in the CIO, and inadequate IS department service are a few the other reasons why firms outsource IS.

Environmental factors
This include factors such as the imitative behaviour among firms, pressure from vendors, positive stock market reaction to the phenomenon, and extensive coverage in the popular press.

Table 2: Study technical specifications

\begin{tabular}{lll}
\hline Scope & Spain & \\
Population & 4.416 largest Spanish business (by \\
Sample size & sales) & \\
Sampling error & $5 \%$ & \\
Survey date & June-October, 2001 & \\
\hline
\end{tabular}

Table 3: General characteristics of the firms 


\begin{tabular}{|c|c|c|}
\hline Outsourcing & $\mathrm{N}$ & $\%$ \\
\hline No & 51 & 14.3 \\
\hline Yes & 306 & 85.7 \\
\hline \multicolumn{3}{|l|}{ Outsourcing Level } \\
\hline Below the mean & 175 & 49.0 \\
\hline Above the mean & 182 & 51.0 \\
\hline \multicolumn{3}{|l|}{ Staff } \\
\hline $0-50$ & 22 & 6.2 \\
\hline $51-500$ & 202 & 56.6 \\
\hline More than 500 & 132 & 36.9 \\
\hline Lost & 1 & 0.3 \\
\hline \multicolumn{3}{|l|}{ Sales (billions of pesetas) } \\
\hline Up to 5 & 36 & 10.1 \\
\hline More than 5 up to 50 & 227 & 63.6 \\
\hline More than 50 & 93 & 26.0 \\
\hline Lost & 1 & 0.3 \\
\hline \multicolumn{3}{|l|}{ Sector } \\
\hline Industry & 210 & 58.8 \\
\hline Services & 118 & 33.1 \\
\hline Financial and insurance institutions & 29 & 8.1 \\
\hline \multicolumn{3}{|l|}{ IS staff } \\
\hline 1-10 Employees & 240 & 67.2 \\
\hline 11-100 Employees & 96 & 26.9 \\
\hline 101-400 Employees & 5 & 1.4 \\
\hline Lost & 16 & 4.5 \\
\hline \multicolumn{3}{|l|}{ IS budget percentage } \\
\hline $0-4$ & 133 & 37.2 \\
\hline $5-10$ & 61 & 17.1 \\
\hline $11-30$ & 18 & 5.1 \\
\hline Lost & 145 & 40.6 \\
\hline
\end{tabular}

Table 4: Outsourcing reasons

\begin{tabular}{|c|c|c|c|}
\hline Reasons & $\mathrm{N}$ & Valid \% & $\begin{array}{c}\text { Rankin } \\
\text { g }\end{array}$ \\
\hline Focus on IS strategic issues & 176 & 49.3 & $1 \mathrm{st}$ \\
\hline Increased IS department flexibility & 144 & 47.1 & 2nd \\
\hline Improved IS quality & 122 & 39.9 & 3rd \\
\hline Elimination of troublesome, everyday & 118 & 38.6 & 4th \\
\hline problems & 106 & 34.6 & 5 th \\
\hline Staff cost saving & 94 & 30.7 & 6th \\
\hline Increased access to new technologies & 62 & 20.3 & 7th \\
\hline Technology cost saving & 39 & 12.7 & 8th \\
\hline $\begin{array}{l}\text { Providing alternatives to in-house IS } \\
\text { Joining the fashion }\end{array}$ & 3 & 0.8 & 9th \\
\hline
\end{tabular}

